\title{
THE IMMEDIATE EFFECT OF CROSS-POLLINATION ON THE SIZE AND SHAPE OF BEAN SEED
}

\author{
S. A. WINGARD
}

Virginia Agricultural Experiment Slation, Blacksburg, Virginia

Received August 16, 1926

TABLE OF CONTENTS

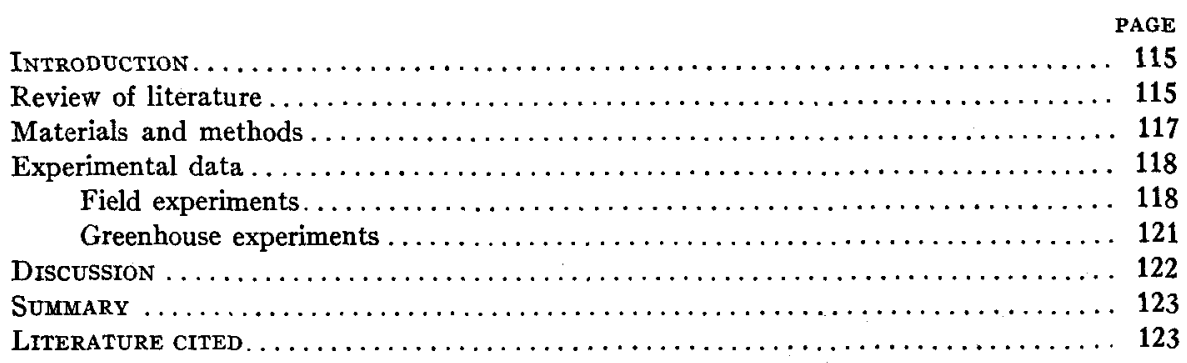

\section{INTRODUCTION}

Several varieties of garden bean, Phaseolus vulgaris, L., were crossed in the greenhouse during the fall of 1918 for the purpose of studying the genetic behavior of resistance to the rust fungus, Uromyces appendiculatus (Pers.) Fries. At harvest the $\mathrm{F}_{1}$ seed of one of these crosses were found to be much larger than the naturally selfed seed grown on the same plants. This impressed the writer as being unusual and for that reason the enlarged $F_{1}$ seed were carefully weighed and measured in comparison with the seed of the parent plants. The results obtained are so striking that they, together with results obtained from further study, are given below.

\section{REVIEW OF LITERATURE}

The immediate effect of crossing on $\mathbf{F}_{1}$ seed in maize has been reported by a number of investigators. Colluns (1909) found that the small seeded Chinese maize showed an immediate increase in size of grain when crossed. Twenty-one $F_{1}$ seed had an average weight of 0.178 gram, while the selfed seed from the same part of the same ear had an average weight of 0.153 gram.

Collins and Kempton (1913) by using mixed pollen in maize crosses obtained a mixture of hybrid and pure seed on the same ear. The im-

1 Paper No. 68 from the Department of Botany and Plant Pathology, Virginia AgriCUltural Expertment Station.

Genetics 12: 115 Mr 1927 
mediate increase in weight of seed due to cross-pollination ranged from 3 to 21 percent. The rate of increase had no direct relation to the size of the seed in the variety used as the source of pollen.

CARrier (1913) reports a case in which he used six thousand kernels each of a pure and a crossed strain of maize. The average weight of $F_{1}$ grains was 2,104 grams, while that of the self-pollinated grains was 1,792 grams, the latter being outweighed by the crossed grains by 17.4 percent. He obtained as much as 30 percent increase in $F_{1}$ grain by crossing different pure-bred strains of the same variety.

There is apparently not so much available data to show that crossing has an immediate effect on the size of bean seed, yet a few cases have been reported.

TSCHERMAK (1922) reports two cases in which the $F_{1}$ seed in bean crosses showed an increase in weight over the selfed seed of the mother parent. In one of these the selfed seed of the mother parent weighed 0.10026 gram, and that of the pollen parent weighed 0.7415 gram, while the $F_{1}$ hybrid seed weighed 0.342 gram. In the other cross the selfed seed of the mother parent weighed $0.10026 \mathrm{gram}$, and that of the pollen parent weighed 0.5732 , while the $F_{1}$ hybrid seed weighed 0.1961 gram. In the first cross the immediate increase in seed weight due to cross-pollination was 241.1 percent, and in the other it was 95.5 percent.

After making an extensive study of bean hybridization, SIRks (1925) writes:

"... from the results thus far obtained from my own artificial crossings. I should like to conclude that the $F_{1}$ seeds will be a little heavier than the selfed seeds if the mother plant is a light and white-seeded one, but that they will show a rather strong metrokliny; if the pollen parent is of a light and white-seeded race, while the mother plant is a coloured and heavy-seeded one, then the $F_{1}$ seeds will be more or less intermediate. The researches concerning this problem of xenia, however, are not finished."

Tschermak (1919) reports that in lima bean crosses xenia was observed in size and shape of seed.

HALSTED (1905) carried four bean crosses through the third generation, and many crosses through the second generation. He makes the following. statement in regard to these crosses:

"As there is no noticeable immediate influence observed in these crosses, the first generation begins with seeds that are, so far as appearances go, the same as those of the mother plant."

BELLING (1913) crossed the Lyon bean with the velvet bean and reports that the crossed seed resemble the ordinary seed of the mother plant. 
Emerson, Shaw and others have made extensive studies of bean hybridization, but the writer has been unable to find any record that would indicate that these workers ever obtained any immediate effect on size of seed due to crossing.

\section{MATERIALS AND METHODS}

The technique used in this work was that which is usually employed in bean hybridization. The flowers were emasculated before the anthers had matured and the desired pollen applied with a camel's hair brush. Certain

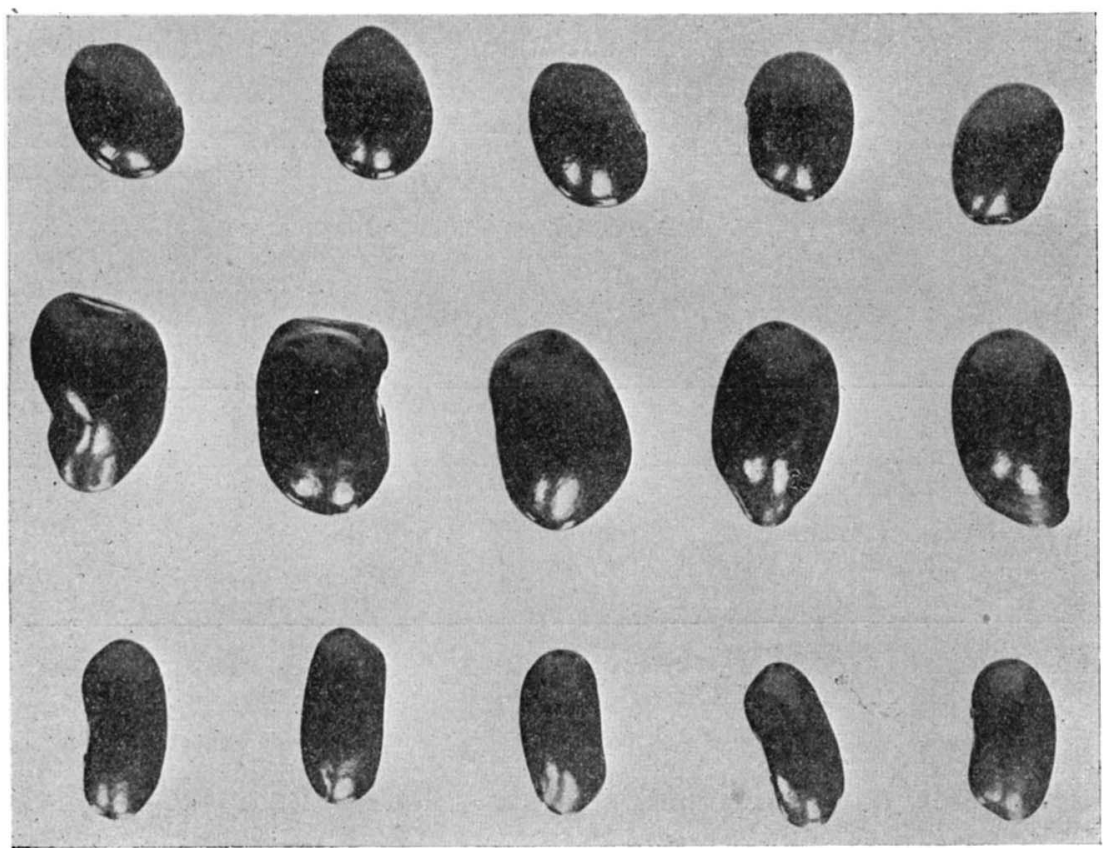

Figure 1.-Top row, seed of Marblehead; middle row, $F_{1}$ seed of Marblehead $\times$ Powell Prolific; bottom row, seed of Powell Prolific.

of the varieties were found to possess very delicate flowers and were very difficult to cross; nevertheless, twenty to thirty seed were obtained from each cross.

Reciprocal crosses were made between the following varieties: Marblehead $\times$ Powell Prolific, Kentucky Wonder $\times$ Horticultural Pole, Kentucky Wonder $\times$ Brockton Pole, Tennessee Greenpod $\times$ Improved Goddard, Tennessee Greenpod $\times$ Yellow Eye, Improved Goddard $\times$ Navy Pea. The $F_{1}$ seed of Marblehead $\times$ Powell Prolific (seed parent always written first) were found to be much larger than the seed of the mother parent 
and also differed in shape as shown in figure 1. The seed of the reciprocal cross, Powell Prolific $\times$ Marblehead, were not visibly different in size and shape from the seed of the mother parent. The $F_{1}$ seed of all other crosses were apparently identical with the selfed seed of the mother parent.

\section{EXPERIMENTAL DATA}

The data in table 1 show the effect of crossing on the weight of $F_{1}$ seed of Marblehead $\times$ Powell Prolific. The $F_{1}$ seed of this cross average 0.382 gram (55.0 percent) more in weight than the selfed seed of the mother parent and an average increase of 0.656 gram ( 155.7 percent) over the seed of the pollen parent. The $F_{1}$ seed of the reciprocal cross, Powell Prolific $\times$ Marblehead, are approximately identical in size and shape with the seed of the mother parent. They show an average increase in size of 0.016 gram ( 3.8 percent) over the selfed seed, a variation that is probably without significance.

TABLE 1

Effect of crossing on weight of $F_{1}$ seed.

\begin{tabular}{|c|c|c|c|}
\hline VARIETY OR HYBRID & NOMBER OF BEED & $\begin{array}{l}\text { TOTAL WETAHT OF SEED } \\
\text { (ORAMS) }\end{array}$ & $\begin{array}{l}\text { AVERAGE WHITHT OP ABSD } \\
\text { (GRAMB) }\end{array}$ \\
\hline Marblehead $\times$ Powell Prolific & 22 & 23.675 & 1.076 \\
\hline Powell Prolific $\times$ Marblehead & 20 & 8.720 & 0.436 \\
\hline Marblehead & 67 & 46.50 & 0.694 \\
\hline Powell Prolific & 20 & 8.40 & 0.420 \\
\hline
\end{tabular}

This increase in size of $F_{1}$ seed is also clearly shown by the measurements of the seed as given in table 2. The $F_{1}$ seed of the Mablehead-Powell Prolific cross average $0.075 \mathrm{~cm}$. (9.6 percent) more in depth, $0.134 \mathrm{~cm}$. (14 percent) more in width, and $0.420 \mathrm{~cm}$. (31.34 percent) more in length than the seed of the mother parent.

TABLE 2

Effect of crossing on size of $F_{1}$ seed.

\begin{tabular}{l|c|c|c|c}
\hline \multicolumn{1}{c|}{ VARIETY OR AYBRID } & NUMBER Or SEED & $\begin{array}{c}\text { AVERAGE DEPTH } \\
\text { (CM) }\end{array}$ & $\begin{array}{c}\text { AVERAGE WIDTH } \\
\text { (CM) }\end{array}$ & $\begin{array}{c}\text { AVERAG LENGTB } \\
\text { (CM) }\end{array}$ \\
\cline { 2 - 5 } Marblehead XPowell Prolific & 22 & 0.852 & 1.091 & 1.760 \\
Powell Prolific X Marblehead & 20 & 0.553 & 0.724 & 1.524 \\
Marblehead & 67 & 0.777 & 0.957 & 1.340 \\
Powell Prolific & 20 & 0.552 & 0.724 & 1.522 \\
\hline
\end{tabular}

FIELD EXPERIMENTS

The $F_{1}$ seed of the Marblehead-Powell Prolific cross were planted in the field in the spring of 1919 along with the seed of the parent varieties from 
the same plants on which the $F_{1}$ seed were grown. The soil was quite uniform in fertility, and the plants were given as nearly identical treatment as possible. A comparison of the number of pods obtained is shown in table 3.

TABLE 3

Effect of crossing on number of pods in $F_{1}$ plants.

\begin{tabular}{l|c|c}
\multicolumn{1}{c|}{ VARIETY OR HYBRId } & NUMBgr OF PLANTS & $\begin{array}{c}\text { AVERAGE NUMBER OF PODS PER } \\
\text { PLANT }\end{array}$ \\
\hline Marblehead $\times$ Powell Prolific & 9 & 87.88 \\
Powell Prolific XMarblehead & 11 & 82.27 \\
Marblehead & 15 & 26.8 \\
Powell Prolific & 20 & 10.7 \\
\hline
\end{tabular}

The $F_{1}$ plants of Marblehead $\times$ Powell Prolific (figure 2, B) averaged 227.9 percent more pods per plant than the Marblehead plants (figure 2, A),

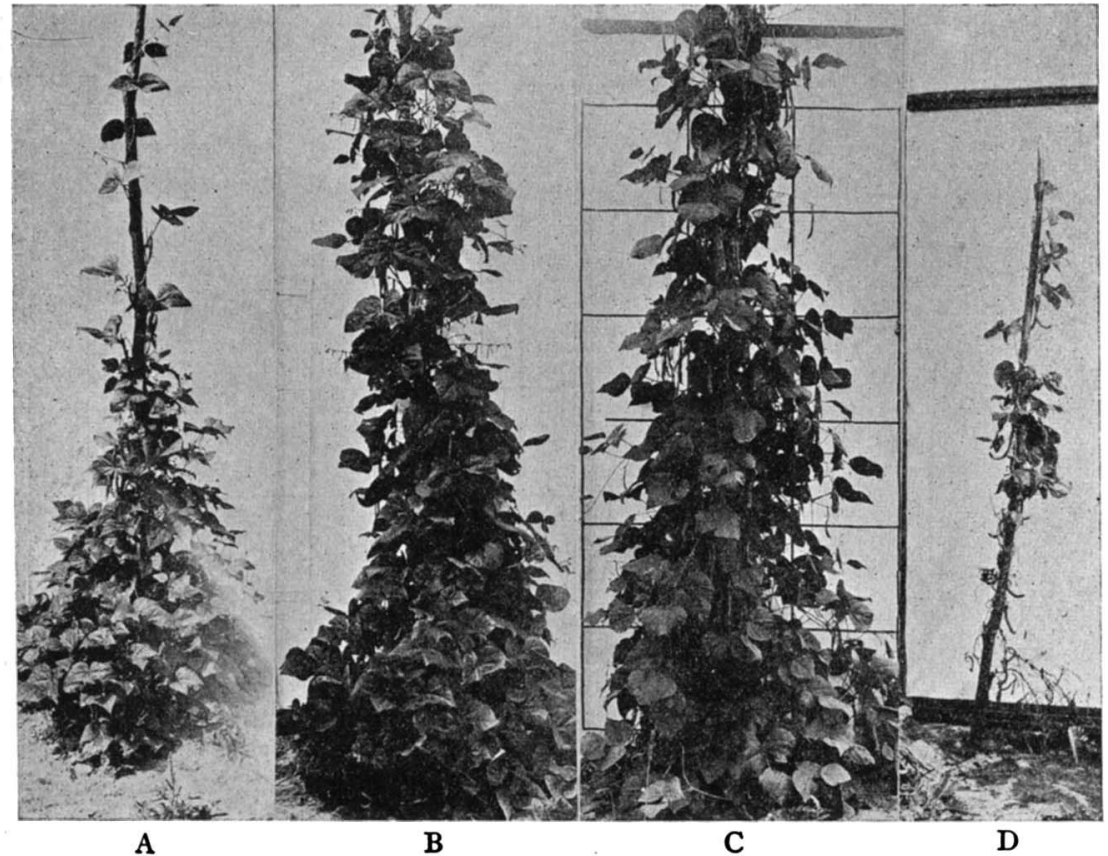

FIGURE 2.-Parent bean plants compared with $F_{1}$ hybrids.

A. Marblehead, (rust resistant).

B. $F_{1}$ hybrid of cross between Marblehead and Powell Prolific with Marblehead as the mother parent.

C. F $_{1}$ hybrid of cross between Powell Prolific and Marblehead with Powell Prolific as the mother parent.

D. Powell Prolific, (very susceptible to rust). 
and an average of 721.3 percent more than the Powell Prolific plants. The reciprocal cross, Powell Prolific $\times$ Marblehead, (figure 2, C) likewise outyielded the Marblehead parent by 206.9 percent, and the Powell Prolific plants by 668.8 percent.

It should be explained that the Powell Prolific plants (figure 2, D) were severely injured by rust and did not have an equal chance with the Marblehead and the $F_{1}$ hybrids which were rust resistant. It is not

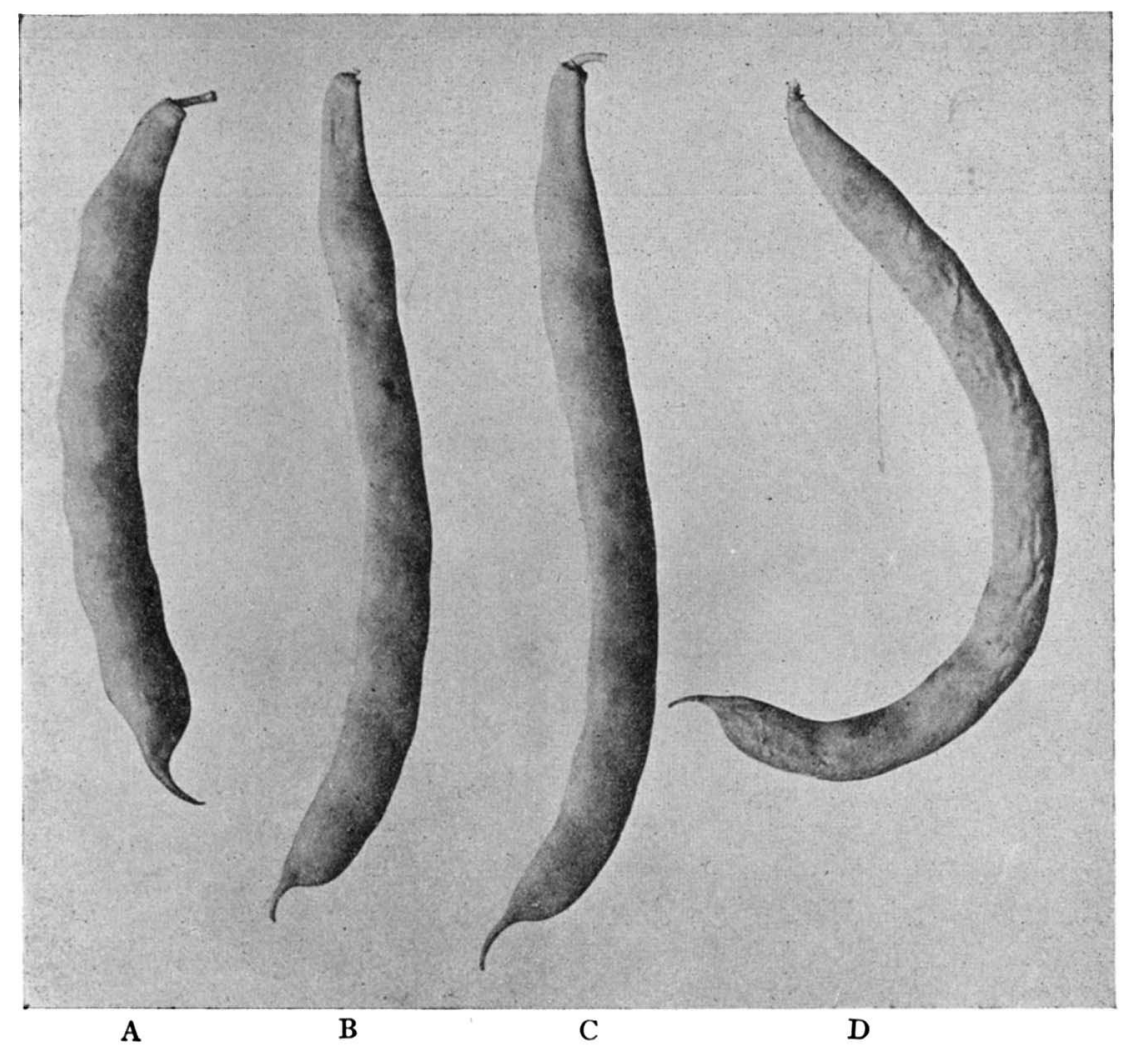

Figure 3.-A, Marblehead pod; B, Marblehead $\times$ Powell Prolific; C, Powell Prolific $\times$ Marblehead; D, Powell Prolific.

believed, however, that the rust injury was sufficient to fully account for the marked difference in pod production of the Powell Prolific plants and the $\mathrm{F}_{1}$ hybrids.

As indicated in the above remarks, rust resistance has proved to be a dominant factor in all my bean crosses. The $F_{1}$ plants have always been rust resistant when the cross was made between resistant and susceptible varieties. No difference has been noted in the rust resistance of the $F_{1}$ 
reciprocals. The $F_{2}$ generation splits up into resistant and susceptible plants in the ratio of $3: 1$. A more complete record of these results will be published in the near future.

The pods from a number of these plants were measured and the number of seed per pod counted. These data which are given in table 4 show that the pods of the $F_{1}$ plants are intermediate in length as well as in number of seed between those of the parent varieties. This is also shown in figure 3 .

TABLE 4

Effect of crossing on length of pod and number of seed per pod in the $F_{1}$ plants.

\begin{tabular}{l|c|c|c|c}
\hline \multicolumn{1}{c|}{ VARIETY OR GXBRID } & NUMBER PLA NTA & NTMBER PODS & $\begin{array}{c}\text { AVRRAG LENGTH POD } \\
\text { (INCEES) }\end{array}$ & $\begin{array}{c}\text { AVERAGR NUMBER } \\
\text { SEED PER POD }\end{array}$ \\
\hline Marblehead $\times$ Powell Prolific & 5 & 556 & 4.204 & 5.26 \\
Powell Prolific X Marblehead & 3 & 324 & 4.337 & 5.67 \\
Marblehead & 6 & 122 & 3.310 & 4.43 \\
Powell Prolific & 4 & 101 & 4.765 & 6.15 \\
\hline
\end{tabular}

\section{GREENHOUSE EXPERIMENTS}

Measurements were made of the length of the first and second internodes and also of the petioles of the primary leaves of $F_{1}$ plants grown in the greenhouse. These measurements are given in table 5 .

TABLE 5

Effect of crossing on length of petioles and internodes in $F_{1}$ plants.

\begin{tabular}{l|c|c}
\hline \multicolumn{1}{c|}{ VARIETY OR HXBRID } & $\begin{array}{c}\text { AVERAGE IENGTH OF FIRST TWO } \\
\text { INTERNODES (CM) }\end{array}$ & $\begin{array}{c}\text { AVERAGE LENGTH OP PETIOLES } \\
\text { OF PRTMARY LEAVES (CM) }\end{array}$ \\
\hline Marblehead $\times$ Powell Prolific & 5.20 & 5.15 \\
Powell Prolific $\times$ Marblehead & 3.60 & 5.66 \\
Marblehead & 8.48 & 7.90 \\
Powell Prolific & 2.30 & 2.80 \\
\hline
\end{tabular}

The median length of the first and second internodes of the parent varieties is $5.39 \mathrm{~cm}$. The average length for the $F_{1}$ plants of the MarbleheadPowell Prolific cross is $5.20 \mathrm{~cm}$, almost exactly intermediate between the parents in length of internodes. On the other hand, the average length of the first and second internodes of the reciprocal cross is only $3.60 \mathrm{~cm}$.

The average length of petioles of the primary leaves for the $F_{1}$ plants of the Marblehead-Powell Prolific cross is $5.15 \mathrm{~cm}$, while that of the reciprocal is $5.66 \mathrm{~cm}$. They are, therefore, almost exactly intermediate between the parent varieties which have a median petiole length of $5.35 \mathrm{~cm}$. The hybrid with the shorter internodes has the longer petioles.

Planimeter measurements were made of the area of the primary leaves of the $F_{1}$ hybrids and of the parent plants. The measurements show that 
the primary leaves of the $F_{1}$ plants of the Marblehead-Powell Prolific cross were 14.8 percent larger than those of the female parent, and 67.0 percent larger than those of the male parent. These data also show that the size of the primary leaf is correlated with the size of the cotyledon.

The $F_{1}$ seed of the reciprocal crosses between Marblehead and Powell Prolific were identical in size, shape and color, and could not be distinguished from each other. They were very similar in size and shape to the selfed Powell Prolific seed but differed from them in color by being finely mottled instead of solid black.

TABLE 6

Effect of crossing on size of leaf of the $F_{1}$ plants.

\begin{tabular}{|c|c|c|c|c|}
\hline VARIETY OR GYBRID & $\begin{array}{c}\text { AVERAQE AREA } \\
\text { OPLIIAZ (SQ IN.) }\end{array}$ & $\begin{array}{l}\text { PERCENTAGE OF IN- } \\
\text { CREASE OVER FEMALE } \\
\text { PARENT }\end{array}$ & $\begin{array}{l}\text { PERGENTAGE OF IN- } \\
\text { CREAGE OR DECREABE } \\
\text { OVER MALE PARENT }\end{array}$ & $\begin{array}{l}\text { AVERAGE WEIGHT } \\
\text { OF FI BEFD } \\
\text { (GRAMS) }\end{array}$ \\
\hline Marblehead $\times$ Powell Prolific & 16.94 & 14.84 & 67.06 & 1.076 \\
\hline Powell Prolific $\times$ Marblehead & 10.49 & 3.45 & -28.88 & 0.436 \\
\hline Marblehead & 14.75 & & & 0.694 \\
\hline Powell Prolific & 10.14 & & & 0.420 \\
\hline
\end{tabular}

\section{DISCUSSION}

There seems no doubt that cross-pollination of certain varieties of beans has an immediate effect on the size and shape of the seed. This phenomenon, although apparently nothing more than a manifestation of hybrid vigor in the embryo, is very rare in beans; and does not occur commonly in an easily recognizable form, or in the very conspicious manner obtained in the writer's experiments. Published records of cases similar to the one described by the writer are rare, although the genetics of the bean plant has been studied intensively by a number of workers. It is of further interest that noteworthy increase in weight and size of $F_{1}$ seed was obtained in only one of the varietal crosses, Marblehead $\times$ Powell Prolific, made by the writer; and that it occurred without exception in a number of these crosses, but in no case in the reciprocal. SIRKs (1925) indicates from his remarks that he believes that the size and color of seed of the parents determine the effect of hybridization in any particular bean cross. In the Marblehead-Powell Prolific cross, the increase in size of $F_{1}$ seed was produced when Powell Prolific, the smaller seeded variety, was used as the source of pollen. Colinss (1913) crossed Algeria and Mexico Black varieties of maize. The grains of the Algeria variety average only one-half as heavy as those of Mexico Black, yet the increases secured in size of $F_{1}$ seed when Algeria was used as a source of pollen were greater then when Mexico Black pollen was used. 
The remarkable increase in pod production of the $F_{1}$ plants over the parents is what one would expect, and is no doubt due to hybrid vigor which is so common in first generation hybrids of both plants and animals.

The area of the primary leaves of the $F_{1}$ plants was found to be correlated with the size of the cotyledons. It is apparent then that the larger the supply of reserve food in the cotyledons, the larger the primary leaves.

It is not surprising to find that rust resistance in beans is a dominant factor, for similar cases have been described for rusts of other plants.

\section{SUMMARY}

Reciprocal crosses were made between the following varieties of bean (Phaseolus vulgaris, L.): Marblehead $\times$ Powell Prolific, Kentucky Wonder $\times$ Brockton Pole, Kentucky Wonder $\times$ Horticultural Pole, Tennessee Greenpod $\times$ Yellow Eye, Improved Goddard $\times$ Navy Pea. Twenty to thirty $F_{1}$ seed were obtained from each cross.

The $F_{1}$ seed of the Marblehead-Powell Prolific cross showed a marked increase in size over the selfed seed of either parent when Marblehead was used as the mother parent. The increase in size of $F_{1}$ seed in the reciprocal cross was very slight and probably without significance. The $F_{1}$ seed of the other crosses were not weighed in comparison with the naturally selfed seed of the parents, but none of them showed any noticeable increase in size over the seed of the parents.

The $F_{1}$ plants of all the crosses were more vigorous and produced more pods than either parent. In the Marblehead-Powell Prolific cross the $F_{1}$ plants made an average increase in pods of 227.9 percent over Marblehead and 721.3 percent more than the Powell Prolific. The plants of the reciprocal cross made about the same yield.

The pods of the $F_{1}$ plants of the Marblehead-Powell Prolific cross were intermediate in length between the pods of the parents.

The area of the primary leaves of the seedlings were found to be correlated with the size of the cotyledons.

All $F_{1}$ plants from crosses made between rust-resistant and rustsusceptible varieties were found to be rust-resistant, rust resistance being a dominant factor.

In the $F_{2}$ generation, rust-resistant and rust-susceptible plants were produced in the ratio of $3: 1$.

\section{LITERATURE CITED}

Belling, John, 1913 Crossing legumes. Univ. of Florida Agric. Exp. Sta., Press Bull. 204: 1-2.

Carrier, Lyman, 1913 The immediate effect on yield of crossing strains of corn. Virginia Agric. Exp. Sta. Bull. 202: 1-11. Figs. 1-2.

GENETICS 12: Mr 1927 
Collins, G. N., 1909 A new type of Indian corn from China. U. S. Dept. Agric., Bureau of Plant Industry. Bull. 161: 1-30. Pls. 1-2.

Collins, G. N., and Kempton, J. H., 1913 Effects of cross-pollination on the size of seed in maize. U. S. Dept. Agric., Bureau of Plant Industry Circ. 124: 1-32. Figs. 1-3.

Halsted, B. D., 1905 Notes upon bean crosses. New Jersey Agric. Exp. Sta. Ann. Rept. 26: 478-480. Pl. 8 .

Sirks, M. J., 1925 The inheritance of seed weight in the garden bean (Phaseolus vulgaris). Genetics 7: 120 .

TSchermak, E., 1922 Über die Vererbung des Samengewichtes bei Bastardierung Verschiedener Rassen Von Phaseolus vulgaris. Zeitschr. indukt. Abstamm. u. Vererb. 28: 23-52. Figs. 1-2.

1919 Über Zuchtung landwirtschaftlich und gartnerisch wichtiger Hulsenfruchter. Arbeit. Deutsch. Landw. Gesell. 1919: 80-106. 